УДК:341.1

DOI: $10.31733 / 2078-3566-2021-1-42-48$

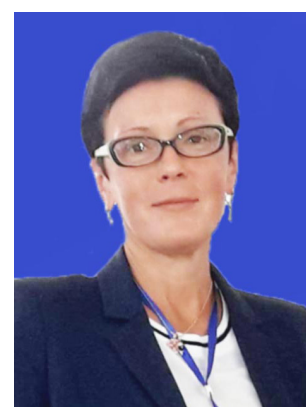

Iryna ALEKSEENKO ${ }^{\circ}$

Dr of Political Sciences, Professor

(Dnipropetrovsk State University of

Internal Affairs)

\title{
INTERNATIONAL TERRORISM AS A POLITICAL PHENOMENON. PROBLEMS OF COUNTERACTION
}

Алєксєєнко Ірина. Міжнародний тероризм як політичний феномен. Проблеми протидії. У статті аналізуються та узагальнюються різні теоретико - методологічні підходи до мікрополітики, у фокусі уваги якої традиційно перебуває людина, а також виходять на перший план фундаментальні проблеми світоустрою, проблеми сталого розвитку і пов'язані з ними зміни, які переживає світ, суспільство, людина в умовах глобалізації, коли мережа взаємозв'язків структурних одиниць мегасуспільства настільки ускладнюється, що зв'язки на мега-, макро-, мезорівнях безпосередньо фокусуються в окремо взятій особистості на - мікрорівні. Визначено, що тенденція до розгляду мікрополітичних проблем у контексті глобалізації, свідчить про поступове розширення взаємозв'язків світової і мікрополітики як наукових сфер дослідження, спільним предметом яких стає аналіз проблем глобальної й особистої безпеки, демократизації глобального політичного процесу, забезпечення керованості глобальним розвитком на всіх рівнях організації.

Обгрунтовано, що сучасні процеси глобалізації відображають потребу ствердження пріоритету загальнолюдських цінностей, що для забезпечення довгострокової глобальної безпеки і сталого розвитку засобами політики важливим $€$ розуміння механізмів функціонування світу глобальної політики, в якому істотне значення відіграють характер діючої політичної культури й політичної свідомості.

Доведено, що символічним осередком глобальних викликів сучасності як сукупностей найгостріших глобальних проблем, які постають перед світовою цивілізацією на початку XXI ст., став феномен міжнародного тероризму і його різновид - глобальний терор як терор нового типу, що, на відміну від традиційного терору спрямований проти конкретних осіб, характер демоциду (масових убивств).

Визначено, що тероризм являє собою виклик суверенітету націй-держав їх монополії на насильство. За своєю природою він транснаціональний і нівелює здатність суверенних держав контролювати транскордонні зв'язки. Тероризм став методом нав'язування своєї волі шляхом незаконного (несанкціонованого системними нормами) застосування насильства, підриву монополії сучасної держави на насильство - ключового компонента суверенітету.

Виявлено, що тероризм сам значно впливає на розгортання глобальних процесів. Він не зупиняється на кордонах держави, а створює мережу відносин, що перетинають кордони таким чином, що боротьба з тероризмом вимагає міжнародних зусиль і набуває транскордонного характеру.

Концептуалізовано, що світова політика орієнтована на розв'язання проблем, породжуваних глобалізацією. Глобального характеру сьогодні набуває проблема безпеки в глобалізованому світі. Світова політика наголошує на питаннях глобальної безпеки в тісному зв'язку з проблемами особистої безпеки, як стану захищеності життєво важливих інтересів особистості.

Визначено, що світова політика орієнтована сьогодні на пошук ефективних рішень проблем безпеки і вбачає їх у створенні глобальної системи протидії сучасним загрозам і викликам глобалізації. Система покликана забезпечувати міжнародну стабільність і стійкий розвиток на тривалу перспективу насамперед на основі політичного регулювання глобальних процесів. Світова політика знаходиться перед необхідністю встановлення нових пріоритетів політики глобальної безпеки, можливостей і засобів

(C) Alekseenko I. V., 2021

ORCID ID: https://orcid.org/0000-0002-6873-003X

irina_alekseenko@yahoo.com 
політичного регулювання глобальної сфери.

Ключові слова: глобалізація, тероризм, людська безпека, демочид, світова політика, стійкий розвиток, глобальні загрози.

Introduction. Terrorism, in any form of its manifestation, has become one of the most dangerous in its scale, unpredictability and consequences of socio- political and moral problems. Today, the issue of countering global terrorism has moved from the theoretical stage to the stage of practical cooperation between states that seek to maintain strategic stability and prevent undermining the foundations of functioning of public and civil institutions. This general position would be correct if not for one circumstance: theoretical political-legal and economic problems of terrorism, dialectical ratio of its specific purpose and means of its achievement, its historical and transitional nature, etc., all this is little or no study. In the opinion of a number of researchers, terrorism is a phenomenon that does not have a past on a historical scale.

The most researched domestic science, from the point of view of internal national security, is its information component, in particular the methods of its provision (V. Konakh, Y. Maksimenko), the development of international cooperation in this field (Y. Romanchuk), the role in the context of European integration (D. Dubov) and the fight against terrorism (I. Alekseenko, D. Kislov), the mechanisms of implementation in a particular region (V. Kozubsky) or in the media space (G. Saschuk).

The military aspects of national security have also been analyzed in detail, including from the point of view of the states military might (V. Smolyanyuk), integration with NATO (V. Panasyuk, I. Fanin), threats of intensifying information wars ( V. Petrov), etc.

At the same time, these studies are based on the concept of national security, in which the state plays a leading role, so the focus on the priority of human security in the context of reconceptualization, which took place in the late twentieth century, has not yet been fully reflected in the works of domestic researchers. This is what made this scientific research relevant.

Findings. Only from the 1960s and 1970s, terrorist attacks became widely used as a means of political struggle and methods of influencing political processes taking place in society, and therefore the world community was faced with the need to intensify counteraction to acts of international terrorism. It should be noted that the geographic scope of terrorist activity, which has now spread to almost all regions of the world, has expanded considerably. As a response to this, the cooperation of the states in the fight against terrorism has intensified. However, against the backdrop of the general accumulated experience of legislative and practical work in this area, the need for its synthesis and analysis has sprung up through the prism of possible creative use in the development of international and national concepts of the fight against terrorism.

Systematizing the existing practice of coordinating the efforts of the international community in countering acts of terror, it should be noted that it is based on a number of universal international conventions. Among them: The International Convention for the Suppression of Unlawful Seizure of Aircraft (1970); the Convention for the Suppression of Unlawful Acts against the Safety of Civil Aviation (1971); the Convention on the Prevention and Punishment of Crimes against Internationally Protected Persons, including Diplomatic Agents (1973); the European Convention against Terrorism (1977); the Convention against the Taking of Hostages (1979); the Convention for the Suppression of Unlawful Acts against the Safety of Maritime Navigation (1988); Convention for the Suppression of Terrorist Bombings (1997); Convention on the Marking of Plastic Explosives for the Purpose of Detection (1999); Convention for the Suppression of the Financing of Terrorism (1999), as well as United Nations Security Council Resolution 1373 on Combating International Terrorism, etc.[6]

Important activities in the framework of international cooperation in combating terrorism are being carried out by international organizations and the main policy outcome documents have been developed. Thus, the Declaration and Program of Action adopted at the United Nations World Conference on Human Rights on 25 June 1993 in Vienna states that acts, methods and practices of terrorism in all its forms and manifestations are activities aimed at the destruction of rights, freedoms and democracy and pose a threat to territorial integrity and security.[3]

The adoption of national laws to better control the production, trade and export of arms and explosives was highlighted in a separate paragraph. The document obliged the signatories to abandon any passive or active support for terrorists and to strengthen legal measures to prosecute terrorist activities; to bring to trial any person accused of committing, preparing or assisting in the commission of terrorist acts. It was also recommended that all States prevent the movement of terrorist groups and their individual members and, to that end, introduce stricter border controls and rules on identity and visa documentation. 
The expert group on transnational organized crime, meeting in Paris on 12 April 1996, adopted a number of recommendations, such as: States should review their legislation relating to criminal offences, identify a central authority whose structure should be appropriate to the rapid transmission of requests for acts of terrorism and those under preparation. Criminal acts, methods and practices of terrorism, as well as the expressed determination to act to eradicate them, both bilaterally and through multilateral cooperation, were condemned.[7]

In the summer of 2005, the European Union drew a line under the previous development of the European community and developed a new vision for the continent. The European Commission's particular focus was on the security of European citizens and the fight against terrorism. The European Commission has prepared the link of key security events in Europe. It is called «Improving European industrial capacity in security research». The proposed measures aim at bridging the gap between civil research supported by EU programs and national and interstate security initiatives. These measures are part of the EU's Seventh Framework Program (2007-2013). Among the selected projects are: improved protection of rail and subway passengers; safer European borders; protection of computers connected to networks; airline safety information network and training; faster and more effective crisis management, airline protection; path to safety: intelligence compatibility; crisis management: real-time monitoring of people indoors; safety research information support network; interface standardization in harbors and at border crossings; unmanned aviation: air surveillance devices; innovative technologies for security and protection of privacy and human rights; exchange of classified information.[9, p.52]

The world's leading countries have come to realize that the criminal world has come together much earlier than their law enforcement agencies have realized that terrorism can only be defeated through joint efforts. Thus, the Law of Ukraine «On Combating Terrorism» states that terrorism is a common challenge against all countries, requiring a joint response, and today all countries of the world must unite to fight this threat, to defeat this evil.[11]

As for the situation in the post-Soviet republics, it should be noted that the criminal world, in contrast to the political world, with the destruction of the common legal space in the former Soviet Union, quickly consolidated. Deprivation of law enforcement agencies and special services of the former Soviet republics of a single core led to fragmentation of their efforts, which was immediately used by criminals. Recent years have seen an increase in the number of serious crimes of a transnational nature. Various manifestations of terrorism, drug trafficking and smuggling of weapons and military equipment are widespread.

A number of major inter-State instruments have been signed since 1991 to coordinate the efforts of the competent authorities of Commonwealth of Independent States Member States to combat terrorism and other dangerous crimes. Among them: The Agreement on the Concept of Military Security of the Member States of the Commonwealth of Independent States is a set of agreed and officially accepted views on the protection of the CIS Member States from external threats, ensuring territorial integrity and political stability, as well as an agreement on cooperation in the field of prevention and elimination of consequences of natural and man-made disasters. In 1995-1996, the Concept of Formation of the Information Space of the Commonwealth of Independent States was adopted, and included a set of measures and conditions of mutually beneficial development of interstate information exchanges in the interests of cooperation of the CIS member states in these areas of activity and in accordance with international principles of information dissemination, as well as the Concept of Collective Security of the Collective Security Treaty states, which recognized The most important stage in the codification of the activity was the adoption in 2000 of the Concept of Collective Security of the States Parties to the Collective Security Treaty. The Council of Heads of State of the Joint Action Program to Combat Crime for the period up to 2002. [4]

However, it should be noted that the provisions referred to in the international instruments discussed above are usually not sufficiently specific, which significantly slows down their use by law enforcement and intelligence agencies of States for specific practical purposes.

If we look at the legislation of the United States, Italy, the United Kingdom, France and other countries, then its analysis allows us to identify certain regularities in the fight against terrorism:

- Codification of legislative norms in the field of combating terrorism contributes to its more effective implementation;

- Domestic law should respond in a timely manner to changes in international treaty practice in this regard, consistently reflecting all its positive aspects;

- Despite the trend towards democratization of their legislation in the developed world, States provide for a higher degree of responsibility and punishment for terrorist acts and participation in terrorist activities;

- When preparing and adopting legislative and other normative acts regulating the fight against terrorism, it is advisable to proceed from the peculiarities of the complex socio-political 
and criminogenic situation in the country or region, rather than to adhere to the so-called principle of modeling.[15]

Thus, according to the author, it is obvious that in order to combat this common threat it is necessary to unite the efforts of all state and public structures, branches of government, mass media. A strategy to combat terrorism is needed.

Today, international terrorism creates additional challenges for national and international security, requires the improvement of anti- terrorist policy measures and the fight against terrorism at both the national and international levels. The efforts of many countries are aimed at strengthening protection against the terrorist threat. From the current trends of counterterrorism, we can highlight the following:

International cooperation and information exchange between countries on counter-terrorism issues. This was the subject of discussion at the meeting of the United Nations Security Council on 12 December 2016, when resolution No. 2322 (co-authored by Ukraine) was adopted calling on States to strengthen and expand inter-State cooperation and mutual assistance in the field of combating terrorism, exchange of information on terrorist organizations and terrorist fighters, including their biometric and biographical data. Emphasis is placed on the importance of judicial and law enforcement cooperation in the investigation of terrorism-related offences.[13]

In this context, we can highlight as an example of the long-term cooperation on counterterrorism the U.S. interaction with the European Union (primarily France, Germany and the United Kingdom), which has been expanding since 2001, when the administration of George W. Bush signed a key agreement with the EU Police Service (Europol). This enabled the exchange of strategic and technical information on counter- terrorism, money laundering, and illicit trafficking in drugs, nuclear, radiological substances and human beings. Supplementary agreement concluded in 2002 Europol and the US authorities have allowed for the exchange of personal data of suspects and have also introduced the institution of liaison officers. Cooperation between the EU and the U.S. has since expanded to include counterterrorism financing, illegal migration and foreign terrorist fighters. Extradition procedures have been simplified and legal cooperation has been strengthened (for example, joint investigation teams or videoconferences on specific criminal proceedings have been introduced).[12]

Two new agreements with Europol on countering illegal migration and foreign fighters were signed by the relevant U.S. agencies in February 2015, providing a platform for information exchange regarding individuals who facilitate the recruitment, transfer and financing of foreign fighters.[17, p.79]

At the national level, strengthen cooperation and exchange of information on counterterrorism issues among the competent authorities. A number of measures have been taken by EU Member States, primarily to improve the efficiency of interaction and information exchange between national intelligence and police services, as well as to strengthen border control. Based on information provided by the Anti-Terrorist Group (The Hague), in 2016, a single database was created, in which more than 20 European intelligence services have access in real time. It is planned to implement a pilot project on automated data exchange between law enforcement agencies of the EU member states regarding persons with criminal records. Also, the work on the introduction of the European Travel Authorization Information System is being intensified.[1, p.77]

Prevention of terrorism, including counteraction to radicalization. Today, specialized programs have been introduced and are being implemented in many countries to prevent the spread of extremist views in society, to prevent young people from being drawn into terrorist organizations, and to apply procedures for granting amnesty to individuals who have participated in terrorist activities and adapting them to peaceful life. Thus, a new OSCE Special Representative has been appointed to coordinate the exchange of experience gained through the implementation of such programs by the 57 member countries of the organization. Governments have drawn attention to the possibility of radicalizing people in places of detention. In order to prevent this threat, the PRC is now considering isolating convicted terrorists from other prisoners.[16]

Introduction of new technologies to combat terrorism by state authorities. The establishment of the European Centre for Combating Terrorism and Radicalization on the Internet is planned to promote and recruit new followers, given the active use of the Internet and social networks by terrorist organizations. This will be part of the Europol Internet reference office. In the Czech Republic, the Centre for Combating Terrorism and Hybrid Threats has recently been established within the Czech Ministry of the Interior, focusing on Internet content analysis and response. In the U.S., another area of interest is the fight against terrorism, given the specifics of the 2016 terrorist attack in Nice, France, when the attacker used a truck.[10, p.179]

For example, in the United States alone, some 250 million vehicles will be connected to the Internet of Things by 2020, which can be managed through the World Wide Web, enabling terrorists 
to intercept the management of such assets and carry out terrorist attacks remotely, even without crossing the national border.

Therefore, in the U.S.A. Department of Justice, in view of such a potential threat, a separate group that deals solely with Internet matters has begun to function.

4. It is necessary to specify the sources and determinants of terrorist manifestations, which may include: a sharp drop in living standards of the population, reduction or lack of social protection, strengthening of social injustice, exacerbation of political struggle, growth of nationalism and separatism, imperfection of legislation, decline in the authority of the authorities and its representatives' ill-considered decisions.[7]

Analyzing the state of the fight against terrorism in Ukraine, it should be noted that currently the Concept of the fight against terrorism (hereinafter - the Concept), adopted by the Decree of the President of Ukraine on April 23, 2013 No. 230/2013, according to which the main threat to Ukraine is the activity of international terrorist organizations. Thus, it states: «Currently, due to the effective implementation of domestic and foreign policy of Ukraine, it does not apply to states with a high probability of terrorist acts or terrorist attacks on their territories by international terrorist organizations against their representations abroad. In Ukraine, there are no internal prerequisites for the emergence of organizations that have used terrorist methods as a means of achieving political goals or drawing public attention to their ideological or other views».[4]

It is clear that such an assessment of the terrorist threat is no longer true. However, it is difficult to disagree with the Concept's definition of a number of external and internal factors that may become the basis for increasing the level of the terrorist threat in the country. Analysis of the activities of international terrorist organizations and the conduct of ATU in Ukraine in recent years allows us to expand the list of such impacts. This document identifies eight main directions of implementation of measures and five priorities of the state policy in the field of combating terrorism, based on a comprehensive systemic approach to solving the problem and covers all generally recognized components of the process of countering terrorism, including: prevention of terrorist activities, detection and cessation of such activities, elimination and minimization of its consequences, as well as information, scientific and other support for the fight against terrorism, international cooperation in combating terrorism.[18, p.46]

Thus, it is advisable to identify the priorities of the state policy in the field of counterterrorism, including the following:

- Prevention and elimination of threats to the life and security of citizens, the interests of society and the State, which arose as a result of the Russian Federation's aggression against Ukraine, and had an armed conflict on the territory of Donetsk and Luhansk oblasts;

- Ensuring the necessary level of anti-terrorist protection after returning to the control of certain areas of the Donetsk and Luhansk regions;

- predicting and suppressing possible terrorist manifestations in the rest of Ukraine as a result of Russia's hybrid aggression;

- Updating the effectiveness of the unified state system of prevention, response and termination of terrorist acts and minimizing their consequences.

We can agree with the idea of domestic researchers that the main tasks in the field of improving the state system of counterterrorism in Ukraine are:

- Regulation of the procedure of interaction between the subjects of the fight against terrorism in various situations;

-The procedure for interaction between the State and citizens and society in the implementation of the main objectives of State policy in the relevant area (ensuring public awareness of the danger and the scale of response to the threat, including):

- Prevention (avoidance of involvement in terrorist activities);

- Prosecution (cessation of terrorist attacks and investigations); Strategic context;

- Protection (improving the security of suspending terrorist attacks);

- Preparedness (minimizing the consequences of an attack and early recovery);

- the actions of a foreign country

Besides, the following questions require special study: terrorism is generated by growing contradictions between the West and the East, the North and the South, it is not one of the causes of terrorism «hybrid» and local wars, which are sometimes waged by reactionary forces of so-called «civilized» states against «uncivilized» peoples, what is the role of arms and drug trafficking in the emergence of terrorism?

Conclusions. The world policy is focused today on the search for effective solutions to security problems and sees them in the creation of a global system to counter modern threats and challenges of globalization. The system is designed to ensure international stability and sustainable 
development in the long term, primarily through political regulation of global processes. The international anti-terrorist coalition, as well as the network of mechanisms and agreements created by its participants to ensure security in the world in response to the challenges of terrorism, is considered as the prototype of the system, which is based on a strategy of coercion for short- term prevention of terrorism. At the same time, it is increasingly clear that a strategy of coercion and deterrence of extremism cannot guarantee long- term security in a globalized world. Global politics is faced with the need to set new priorities for global security policy, opportunities and means of political regulation in the global sphere.

The fight against and elimination of terrorism is a long-term process that involves the creation of the necessary objective and subjective conditions to achieve this goal. At the same time, it is impossible to destroy terrorism by force alone: violence inevitably generates new violence.

The most important prerequisite for eradicating terrorism is the stabilization of the economic and political situation in countries and the strengthening of democratic principles in public and political life. It is necessary to form a society in which the social base of terrorism will be sharply reduced. It is especially important that stable democratic political systems, mechanisms of civilized political dialogue and rotation of power are formed in the states. To supplant terrorism from life, a high level of political and legal culture in society is needed, as well as a clear establishment of legal sanctions for terrorist actions.

It is necessary to create favorable conditions for the normal even development of different ethnic groups and ensure the realization of their interests in order to prevent conflicts on the national basis. The task of the states is to form the self-awareness of all ethnic groups living in the given country, at which the feeling of belonging to the state would be a priority before the factor of ethnicity in the process of self-identification of citizens.

In addition, there is a need to strengthen the efforts of State bodies in carrying out preventive activities. Necessary measures to strengthen border protection, increase control over the activities of foreign organizations to minimize the possibility of importing extremism from other countries. Measures aimed at reducing unemployment and solving urgent social and economic problems can reduce social tension in society and neutralize the main source of potential social excesses.

Meetings and agreements at the highest level alone are not sufficient to eradicate terrorism. An effective response to international terrorism requires the development and implementation of a comprehensive program that includes political, social, economic, legal, ideological, special and other aspects. It must take into account the interests of the population, the problems and the conflict-generating potential of terrorism around the world. There is also a need for interaction and coordination of all forces of society interested in solving this topical problem.

One of the most important areas of activity of the heads of state should be joint cooperation to prevent, localize and stop regional outbursts of extremism, as some conflicts caused by terrorists may cause destabilization in other states. The tragic results of terrorism, which characterize modern politics, should serve as an important warning to all political forces that attempts to solve political, economic and other problems with the help of violence do not contribute to the solution of the set tasks, but, on the contrary, lead to the increase and growth of contradictions in society.

\section{References}

1. Arquilla J., Ronfeldt D. (2001) Networks and Netwars. The Future of Terror, Crime and Militancy. Santa Monica. $122 \mathrm{p}$.

2. Dartnell M. (2001) A Legal Inter-Network for Terrorism: Issues of Globalization, Fragmentation and Legitimacy. The Future of Terrorism. M. Taylor and J.Horgan. London. The Macmillan Press. 298 p.

3. Definitions of Community Resilience: An Analysis: A CARRI Report. URL: http://www.resilientus. org/publications/reports.html.

4. E U terrorist list. URL: http://www.consilium.europa.eu/en/ policies/fight-againstterrorism/terrorist-list.

5. European Union Terrorism Situation and Trend Report (TE-SAT). URL:https://www.europol. europa.eu/sites/default/files/documents/europol_tesat_2016.pdf

6. Foreign Terrorist Organizations. Bureau of Counter terrorism URL: https://www.state.gov/j/ct/rls/ other/des/123085.htm.

7. Gunaratna Rohan. After Nice: The Threat Within Europe: URL https://www.rsis.edu.sg/wp-content/ uploads/2016/07/CO16183.pdf.

8. Knutson J. (1980) The Terrorist' Dilemmas: Some Implicit Rules of the Game. Terrorism: An International Journal. № 4. P. 192-296.

9. Merari A. (2001) Terrorism As a Strategy of Struggle: Past and Future.The Future of Terrorism. Eds. Max Taylor and John Horgan. London: The Guilford Press. P. 46-60.

10. Nef J. (1999) Human Security and Mutual Vulnerability: The Global Political Economy of 
Development and Underdevelopment. 2nd ed. Ottawa. 245 p.

11. Pollack Joshua H., Wood Jason D. Enhancing Public Resilience to Mass-Casualty WMD Terrorism in the United States: Definitions, Challenges, and Recommendations. Defense Threat Reduction Agency, Advanced Systems and Concepts Office, Report Number ASCO 2010 042, Contract Number DTRA0103-D0010018.URL:https://fas.org/irp/agency/ dod/dtra/resilience.pdf.

12. Proscribed Terrorist Organisations. UK, May 3, 2017. URL: https://www.gov.uk/government/ uploads/system/uploads/attachment_data/file/578385/201612_Proscription.pdf.

13. Proscribed Terrorist Organisations. URL: https:/www.gov.uk/government/uploads/system/ uploads/attachment_data/file/612076/2017050 3_Proscription.pdf http://www.fsb.ru/fsb/npd/terror.htm.

14. Scholte J. A. (2000) Globalization. A critical Introduction. London: Palgrave. 216 p.

15. Schori Liang Christina. The Criminal-Jihadist: Insights into Modern Terrorist Financing. Strategic Security Analysis. URL: http://www.gcsp.ch/download/6084/137684.

16. Special Report: Building National Resilience to Global Risks. The Global Risks 2013 report, Eighth Edition. World Economic Forum. URL: http://www.weforum.org.

17. Taylor M., Horgan J. (2001) Future Developments of Political Terrorism in Europe. The Future of Terrorism. Eds. Max Taylor and John Horgan. London: Routledge. 231 p.

18. The Global Terrorism Index 2019. The Institute for Economics and Peace andUniversity of Maryland. P. 45-48.URL: http://economicsandpeace.org/wp-content/uploads/2019/11/Global- TerrorismIndex 2019.pdf.

Submitted 12.03.2021

\section{SUMMARY}

One of the main features of international political and legal development is the unresolved problem of national security of the state and international security. This is particularly relevant in the current globalized environment, when the economy, informatization and democratization of international relations create unprecedented opportunities for development, but at the same time increase the vulnerability of the system to terrorism, the use of weapons of mass destruction, etc. Scientists of our time are faced with urgent tasks, the solution of which allows the study of the problems of state creation, especially such important determinants of this process as legal regulation in the field of national and international security of the state in the context of globalization. Proceeding from this, scientific researches in this context, in which the basic principles of organization of national and international security are systematically revealed, are expedient and timely. global threats.

Keywords: globalization, terrorism, human security, democide, world politics, sustainable development,

УДК 340.68

DOI 10.31733/2078-3566-2021-1-48-53

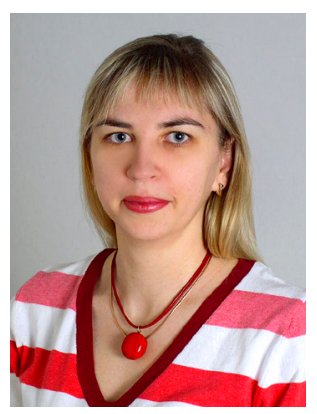

ОльГа МІНЧЕНКО ${ }^{\circ}$

доктор юридичних наук, доцент (Національна академія внутрішніх справ)

Актуальність статті обумовлюється необхідністю залучення до правознавства результатів досліджень, отриманих міжгалузевою наукою - юридичною лінгвістикою, положення якої є важливим методологічним підгрунтям пізнання права в постмодерному суспільстві. Метою роботи $є$ висвітлення важливості розуміння права в сучасних умовах через юридико-лінгвістичну теорію.

Резюмується, що в умовах постмодерного суспільства відбувається переосмислення соціальних явищ, у тому числі й права. Важливим гносеологічним інструментарієм гуманітарної сфери знань стає

(C) Мінченко О. В., 2021

ORCID ID: https://orcid.org/0000-0001-7746-0919

olgaminchenko1004@gmail.com 